\title{
Roof-Top rainwater harvesting system for official / multistoried building with reference to malda district, WB
}

\author{
Dr. Suman Panigrahi
}

\begin{abstract}
Rain water harvesting is received increased attention world wide as an alternative source of water. Roof-top rain water harvesting system is looked upon as one of the most feasible and economical ways of water conservation. With increasing problem of water scarcity, planning and designing roof top rain water harvesting is gaining wider importance to meet ever-increasing water demand, encouraging use of water or more sustainable basis. The rain water harvesting is the simple collection or storing of water for the domestic or the agriculture purpose. The method of rain water harvesting has been into practice since ancient times. The method is simple and cost effective too. Malda district of West Bengal is badly affected by Arsenic contamination in ground water. The present study finds its usefulness in developing awareness towards judicious use of water among masses and efficient ways to harvest roof top rain water resources at institutional / mu ltistoried build ings in Malda district.

Keywords: Roof-top, Rain Water Harvesting, Official build ing, mult istoried build ing
\end{abstract}

\section{INTRODUCTION}

It was very difficult to imagine few decades before that you will require to buy drinking. The use value of water was never undermined, but its about time that even its exchange value is given importance. Fresh water today is scare resource, and it is being felt world over. More than 2000 million people would live under condition of high water stress by the year 2050, according to the UNEP (United Nations Environment Programme), which warns water could prove to be a limited factor for development in a number of regions in the world. In most of the developing countries the fresh water supply comes in the form of seasonal rains, such rains do not provide enough of time for efficient use during the monsoon. India, for instance, gets $90 \%$ of its rainfall during the summer monsoon season, which lasts from June to September. For the rest of the months there is hardly any rain. As a result of the seasonal nature of rain, India can make use of more than $20 \%$ of its potentially available fresh water resources. And it is reported that the per capita availability of renewable fresh water in the country has fallen over last 50 years.

Rain water harvesting, in its broadest sense, is a technology used for collecting and storing rainwater for human use from rooftops, land surfaces or rock catchments using simple techniques such as jars and pots as well as engineered techniques. Rainwater harvesting has been practiced for more than 4,000 years, owing to the temporal and spatial variability of rain fall. It is an important water source in many areas with significant rainfall but lacking any king of conventional, centralized supply system.
It is also a good option in areas where good quality fresh surface water or ground water is lacking. Study area is highly affected by Arsenic pollution. Arsenic is highly toxic and known carcinogenic. seven block are affected by Arsenic out of fifteen block in Malda district. Govt. of West Bengal constructed some APR (Arsenic Removal Plant) but those are not covered the whole area so, rainwater harvesting (rooftop) is the best remedy against Arsenic in the study area. Study area is found so many official building (including school building) and multistoried building having potential roof top catchment where harvesting can be suitably done.

\section{OBJ ECTIVES OF THE S TUDY:}

1. To promote Rooftop rain water harvesting system.

2. To analyze the reduction in water related problems and Arsenic pollution.

3. To analyze the uses of official / multistoried buildings for rooftop rain water harvesting.

\section{STUDY AREA:}

Malda district lies $347 \mathrm{Km}$ North of Kolkata, the State capital of West Bengal (India). The district of Malda in West Bengal has long and rich historical traditions.

Impor tant Statistics :

Population - 3988845

1771

Block - 15

Villages -

Normal Household - 845089

Town -2

Household - 1422

Area - 3733 (Sq.Km)

(Population) - 1069

Literacy $-61 \%$ 


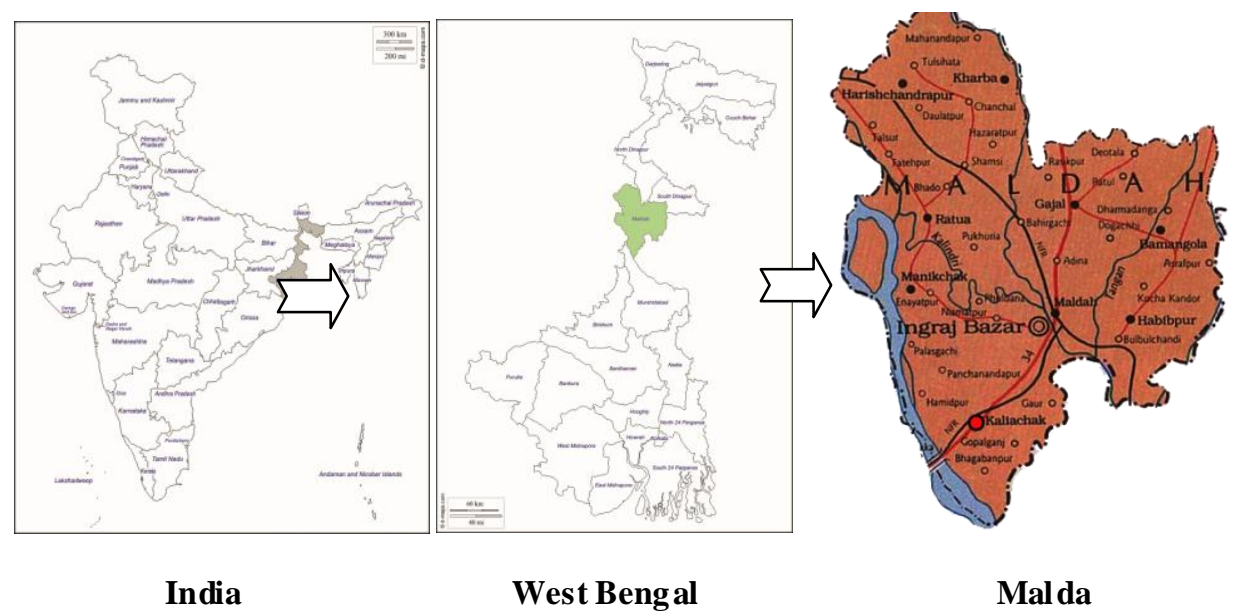

Fig -1: Study area location map

\section{METHODOLOGY}

A descriptive field survey method using key informant interviews was used in the present study. A total of 10 residential building, 10 school building, 7 official building and 10 multistoried building (including flat) covering Englishbazar Municipality, Kaliachak, Gazole and Ratua block were selected to evaluate the potential towards rooftop rainwater harvesting. Focus group discussion, Transect walk helped to study about roof top rain water harvesting. Other necessary details collected from different offices also.

\section{RESULTS AND DISCUSSION:} Need For Rooftop Rain Water Harvesting In The Study Area :
1. To meet the ever increasing demand for water.

2. To avoid flooding of roads.

3. To augment the ground water storage and control decline of water levels.

4. Supply fresh water for Arsenic affected area and reduce ground water pollution.

5. To improve the quality of ground water.

6. To supplement domestic water requirement during summer, drought etc.

Site / Buildings, where rooftop rainwater harvesting system should be installed in the study are a :

In the study area has so many buildings which has huge potential of roof top rain water harvesting.

\begin{tabular}{|l|l|}
\hline $\begin{array}{l}\text { Educational Institution } \\
\text { Buildings }\end{array}$ & $\begin{array}{l}\text { Primary school, SSK, Anganwari, Secondary School, Higher Secondary } \\
\text { School, Madrasah, Girsl School, ITI, College, B.Ed. College, Gourbanga } \\
\text { University, Library, etc. }\end{array}$ \\
\hline Official Buildings & $\begin{array}{l}\text { DM, BDO, Panchayet, Court, Post Office, PWD, BSNL, Railway, } \\
\text { Hospital, Forest Office, SP, Municipality, Police Station, Historical Place } \\
\text { (Adina, Gour), Electric Office. }\end{array}$ \\
\hline Multistoried Buildings & Flat, Shopping Complex, Hotel, Guest House, restrurant. \\
\hline Residential; Buildings & House, Hostel, Mess. \\
\hline Religious Buildings & Temple, Mosque, Church. \\
\hline
\end{tabular}

\section{TYPES OF RAINWATER HARVESTING SYSTEMS :}

Typically, a rainwater harvesting system consists of three elements : the collection system, the conveyance system, and the stotrage system. Collection systems can very from simple types within a household to bigger systems where a large catchment area contributes to an impounding reservoir from which water is either gravitated or pumped to water treatment plants. The categorization of rain water harvesting systems depends on factors like size and nature of the catchment areas and whether the systems are in urban or rural settings.

\section{SIMPLE ROOF-TOP WATER COLLECTION SYSTEMS :}

In the study area total normal household is 845089. While the collection of rainwater by a single household may not be significant but the impact of thousands or even millions of household rainwater storage tanks can potentially be enormous. 


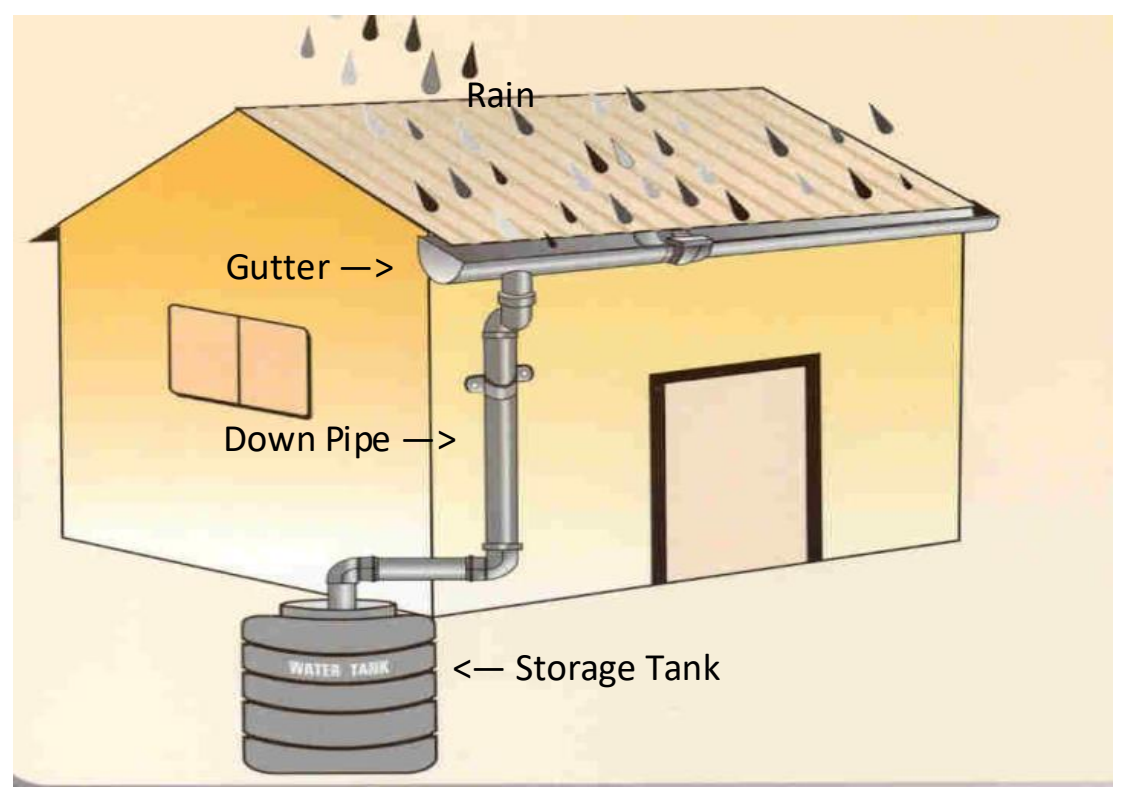

Fig-2: Simple rooftop water collection.

The materials and the degree of sophistication of the whole system largely depend on the initial capital investment. In some cases, the harvested rainwater may be filtered. In other cases, the rainwater may be disinfected.

\section{LARGER SYSTEMS FOR EDUCATIONAL INSTITUTIONS / OFFICIAL B UILDINGS :}

When the systems are larg; the overall system can become a bit more complicated, for example rainwater collection from the roofs and grounds of institutions, storage in underground reservoirs, treatment and then use for non-potable applications. In the study area has total 1422 institutional building (excluding schools) where have huge potential of rain water harvesting.

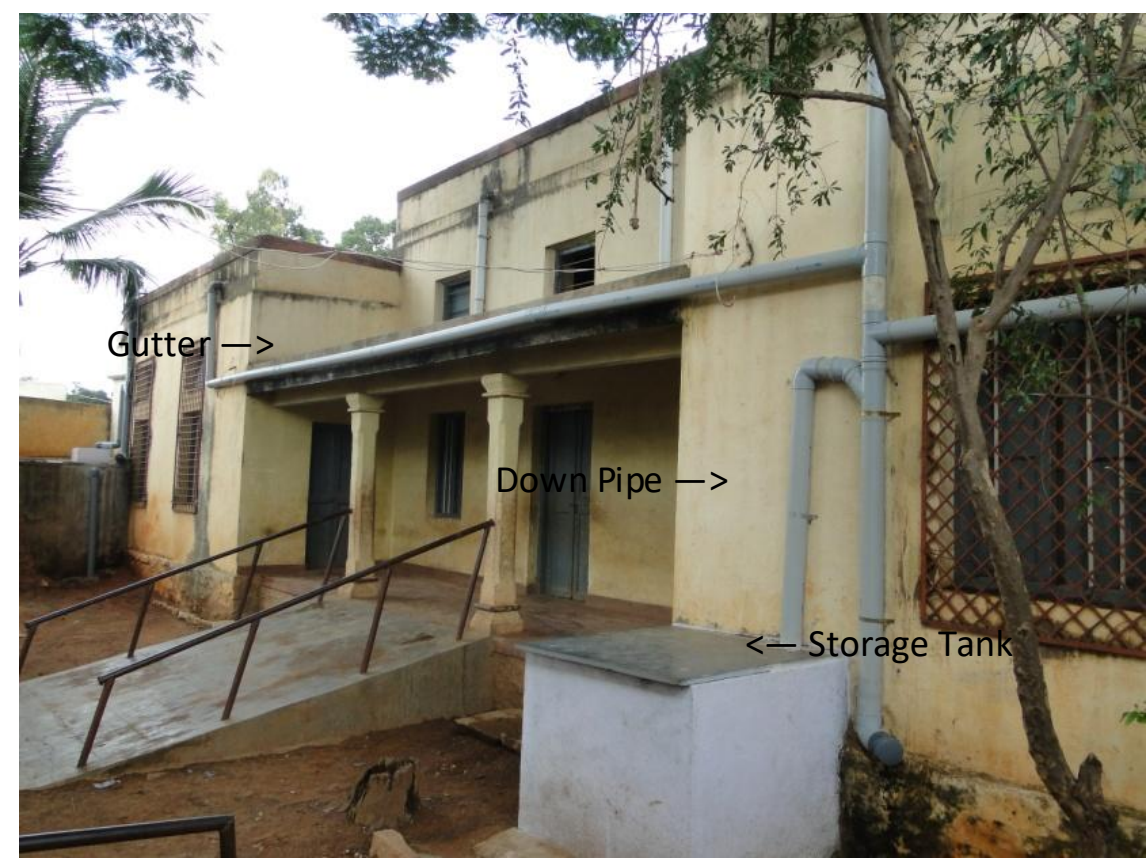

Fig-3 : Rooftop rainwater harvesting in a school build ing. 


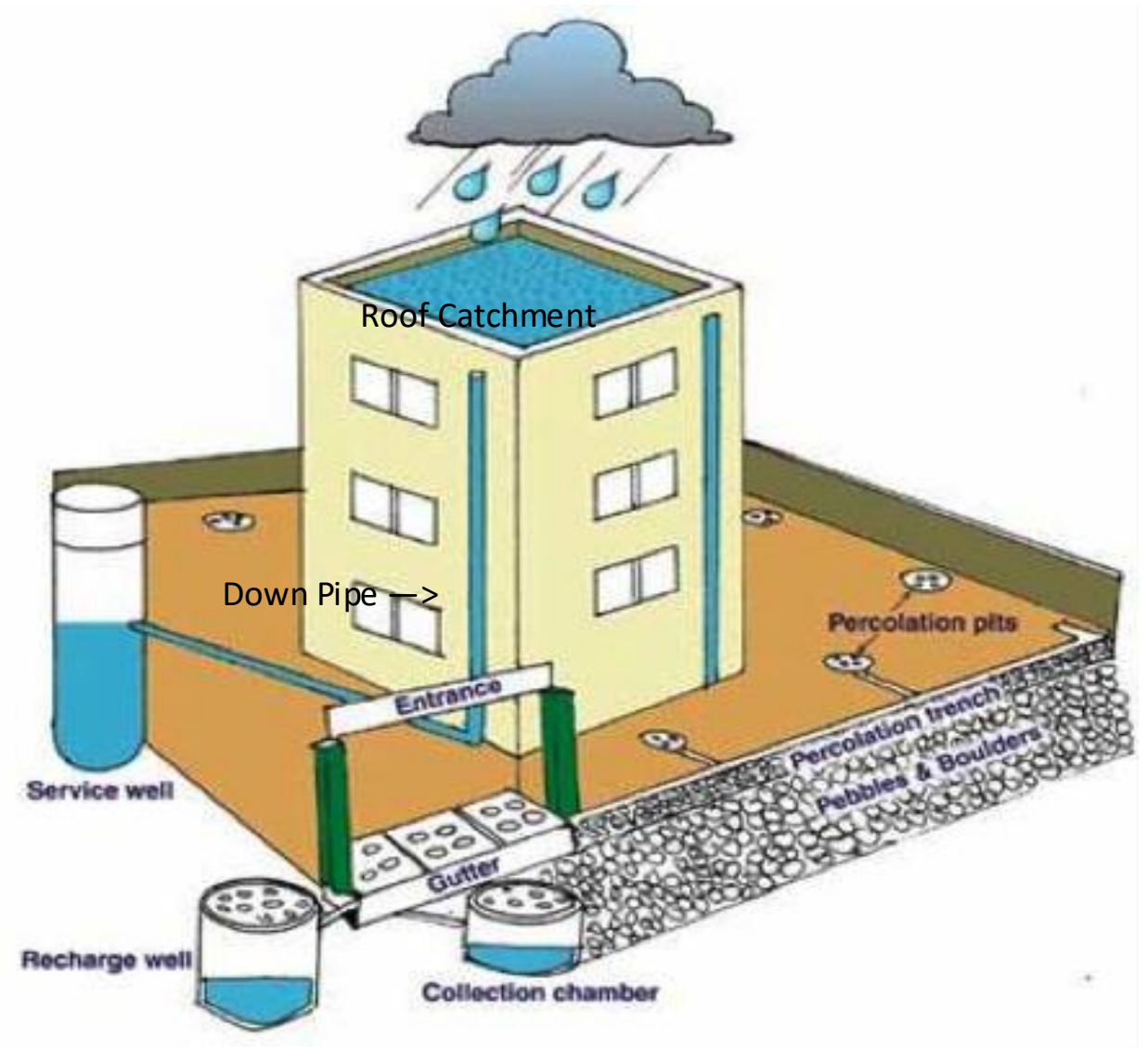

Fig-4 : Rooftop rainwater harvesting mult istoried building.

\section{COMPONENTS OF ROOF-TOP RAINW ATER HARVES TING S YSTEM:}

Rooftop rainwater harvesting systems are usually designed to support the drinking and cooking needs of the family or society. In the study area which is affected by Arsenic pollution, rain water harvesting should help to drink fresh water. In addition, a first flush system to divert the dirty water, which contains debris, collected on the roof during nonrainy periods and a filter unit to remove debris and contaminants before water enters the storage tank are also provided.

\section{COMPONENTS: \\ Roof Catchment \\ Gutters \\ Drain Pipes \\ Down Pipe \\ Filter Unit \\ Storage Tank \\ Pump Unit \\ Recharge Unit \\ Outlet tap/etc.}

\section{ES TIMATED AVERAGE COST OF INSTALLING A WATER HARVESTING SYSTEM :}

1. An individual house : Of average area of 200$400 \mathrm{~m}^{2}$ the average cost will be around Rs. 20000 - 25000. A recharge well will be constructed near the existing borewell. The roof water through PVC Pipe will be diverted to recharge well.

2. An apartment building : The cost will be less since the many people will share the cost. The cost will be around $60-80$ thousands.

3. An institution : With campus, the cost was around 3-4 lac. Here two recharge wells and three trenches cum percolation pits were constructed.

4. A colony : The cost will be much less. For instance, around 36 recharge wells were installed at the cost of 8 lac.

\section{AVERAGE ANNUAL MAINTENANCE COST : \\ Would be around Rs. 200-300 for two labourers once in a year to remove the pebbles and replace the sand from trenches.}




\section{CONCLUSION}

Malda district has huge potential of rooftop rainwater harvesting. An integrated system using full potential of the rooftop rainwater can also supplement the existing water supply and help in recharging the ground water. Seven block out of fifteen blocks are affected by Arsenic in this district; rain water harvesting also help to provide fresh drinking water for those areas. And it should be very usefull for rural school or educational institution also. Institutions / Govt. should be encouraged to practice rooftop rainwater harvesting on their campus/buildings which would promote self-sufficiency and helping to foster an appreciation for this essential and precious resource.

\section{REFERENCES}

[1]. Government of India, 2003, Ground Water in Delhi : Improving the sustainability through Rainwater Harvesting, Central Ground Board. Ministry of water resources.

[2]. A.R. Tembhukar, Anand Gharad, A. Powar, N. Bhalerao and S.D. Prasad, "Rooftop Rain water Harvesting system for institutional campus", 2006, N.S. R.H.W.M., Nagpur, PP-292-294.

[3]. Rainwater Harvesting and conservation, Manual, Govt. of India, 2002, New Delhi.

[4]. B. Sitaram Shetty, "Rain Water Harvesting in costal Districts of Karnataka State, India", 2006, N.S.R.H.W.M, PP-171-173.

[5]. R. A marnath babu, "Roof top Rain Water Harvesting system in Decan Plateau Region, Andhra Pradesh, India" Internet.

[6]. "Rainwater Harvesting and Utilization", UN-HA BITAT, PP-12-13.

[7]. "The Rainwater harvesting Symposium 2005”, Ethiopia, 2015 (Internet).

[8]. Saif Said, "Assessment of Roof-top Rain water Harvesting Potential in South Delhi, India, A case study", 2014, IJERD, PP-141146.

[9]. Indian Standard Roof top Rainwater Harvesting - Guidelines, 2008, BIS, New Delhi, PP-10-13.

[10]. "Manual on Roof top Rainwater Harvesting systems in Schools", www.arghyam.org.

[11]. "Model designs for RWH and AR, (Internet).

[12]. Mrs. S.D. Khandagale and Mrs. V.A. Joshi, "Rain Water harvesting : Grab hold of water where it falls", VPMP, Thane, India.

[13]. "Rooftop Rain Water Harvesting need and advantage" - (Internet).

[14]. "Urban Rain Water Harvesting" CSE, 2014, New Delhi. 